\title{
Penyintas di Lumpur Tanpa Batas: Potret Pemulihan Sosial Ekonomi Masyarakat Terdampak Bencana Lumpur Lapindo
}

\author{
Miftakhul Iftita, Siti Zurinani \\ Program Studi Antropologi, Fakultas Ilmu Budaya Universitas Brawijaya, Malang \\ Email: mifthakuliftita@ymail.com, \\ Email: zurienanis@ub.ac.id
}

\begin{abstract}
THIS -- paper discusses about the socio-economic recovery efforts of communities affected by the Lapindo mud disaster in Kedungsolo, the relocation Village. The data of this paper is taken by using ethnography method, which resulted in the conclusion of the post-disaster socio-economic recovery efforts by the Renokenongo community since the evacuation of Pasar Baru Porong. The Renokenongo community formed the Paguyuban Warga Renokenongo Menolak Kontrak (Pagar Rekontrak) as the beginning of the socio-economic recovery effort communally. While personally, every household also makes different recovery efforts depending on how they access existing recovery resources. This recovery effort also received support from several related parties, both government agencies and private institutions.
\end{abstract}

Keywords: Lapindo, Disaster, Affected Community, Social Economic Recovery

\section{Pendahuluan}

Pada tanggal 29 Mei 2018, bencana lumpur Lapindo di Sidoarjo terjadi duabelas tahun lalu. Penyebab terjadinya peristiwa semburan lumpur kepermukaan tanah di Desa Renokenongo, Kecamatan Porong tersebut telah menjadi perdebatan mulai dari nama bencana, jenis bencana dan juga penyebab semburannya. Meskipun masih menjadik perdebatan yang tak kunjung selesai, Rusdi dan Mukarom (2014: 5-13) menyatakan bahwa lumpur Lapindo telah menghancurkan kehidupan ribuan masyarakat di 17 desa pada tiga kecamatan di Kabupaten Sidoarjo.

Akibat dari bencana tersebut, masyarakat terdampak Lapindo mengalami kerugian yang sangat besar, baik moril maupun materiil. Selain menanggung kerugian kehilangan tanah, rumah, dan mata pencaharian, masyarakat terdampak lumpur Lapindo juga mengalami kerugian sosial ekonomi yang lebih besar lagi. Mereka harus tercerabut dari akar sosiohistoris karena berpindah dari tempat tinggal dan lingkungan sosial lama mereka. Meskipun terdapat upaya relokasi bagi masyarakat terdampak lumpur Lapindo, upaya tersebut bukanlah perkara mudah. Dalam konteks ini, relokasi bukan hanya sekedar perpindahan rumah secara fisik-geografis, tetapi ini adalah proses sosial budaya bahkan ekonomi.

Terkait dengan upaya penanganan bencana lumpur Lapindo, pemerintah membentuk Badan Penanggulangan Lumpur Sidoarjo (BPLS) berdasarkan Peraturan Presiden Nomor 14 
Endogami: Jurnal Ilmiah Kajian Antropologi

E-ISSN : 2599-1078

Tahun 2007 dan dibubarkan melalui Perpres No 21 Tahun 2017 tanggal 2 Maret 2017. Dari hasil audiensi yang dilakukan Komnas HAM dengan BPLS, selaku ujung tombak penanganan lumpur Lapindo, diperoleh fakta bahwa penanganan yang dilakukan hanya sebatas penanggulangan luapan. Selain itu, pemerintah masih berkutat dalam upaya penyelesaian ganti rugi aset warga (Harian Kompas: 2015). Fokus masalah yang masih berkutat pada penanggulangan dan penyelesaian ganti rugi tersebut, mengakibatkan upaya pemulihan sosial dan ekonomi pada masyarakat terdampak bencana lumpur Lapindo masih sangat terbatas.

Di antara sekian banyak wilayah administrasi yang terdampak, salah satu kelompok masyarakat yang menjadi korban sejak tahun pertama lumpur menyembur adalah warga Renokenongo. Sejak awal bencana masyarakat Renokenongo tinggal di pengungsian Pasar Baru Porong hingga Mei 2008 sembari menunggu pembayaran uang ganti rugi. Setelah mendapatkan pembayaran uang muka dari PT. LBI, warga Renokenongo membeli tanah seluas 10 hektare di Desa Kedungsolo, Kecamatan Porong. Mereka mendirikan perumahan Renojoyo guna mewujudkan cita-cita untuk tinggal bersama kembali. Jika ditinjau dari segi perpindahan kolektif, maka Pagar Rekontrak (Paguyuban Warga Renokenongo Menolak Kontrak) adalah kelompok yang terbaik karena kelompok korban lainnya pindah berpencar (Barubara dan Utomo, 2012: 237-241). Uraian di atas memunculkan beragam pertanyaan kritis, salahsatunya adalah bagaimana upaya pemulihan kehidupan yang dilakukan masyarakat terdampak bencana lumpur Lapindo warga Renokenongo jika dilihat dari segi sosial-ekonominya?

Salah satu upaya yang bisa dilakukan untuk menangani bencana adalah dengan melakukan manajemen bencana pasca bencana tersebut terjadi. Siklus hidup manajemen bencana alam dan bencana modern adalah empat aktivitas yang harus dilakukan yaitu mitigasi, kesiapsiagaan, respon, dan pemulihan (Kusumasari, 2014: 21). Jika merujuk pada permasalahan yang diangkat pada tulisan ini, maka dari keempat aktivitas manajemen bencana, tulisan ini akan lebih terfokus pada upaya pemulihan pasca bencana. Pemulihan dalam manajemen bencana adalah kegiatan mengembalikan sistem infrastruktur kepada standar operasi minimal dan panduan upaya jangka panjang yang dirancang untuk mengembalikan kehidupan ke keadaan dan kondisi normal atau keadaan yang lebih baik setelah bencana. Pemulihan dimulai sesaat setelah bencana terjadi (Sullivan dalam Kusumasari: 2014). Coppola (2007: 299) mendefinisikan upaya pemulihan sebagai fungsi dari manajemen bahaya yang dilakukan oleh negara, komunitas, keluarga, dan individu dengan cara memperbaiki, merekonstruksi atau mendapatkan kembali apa yang hilang ketika becana terjadi. Idealnya mengurangi resiko dari kejadian yang sama ketika bencana tersebut terjadi lagi dimasa yang akan datang.

Beberapa penelitian terkait bencana lumpur Lapindo telah dilakukan. Misalnya Oleh Fauzan, A.U dan Batubara (2010) yang berjudul Displacement and Changing Gender and Intergenerational Relations: Experience of Hot Mudflow Affected Families in East Java, Indonesia. Tulisan tersebut membahas dampak bencana lumpur Lapindo secara mikro terhadap rumah tangga warga Desa Kedungbendo, Kecamatan Tanggulangin. Secara spesifik penelitian Fauzan dan Batubara (2010) tersebut bertujuan untuk mengetahui efek perpindahan paksa terhadap rumah tangga korban yang menghasilkan perubahan peran gender dan hubungan 
Endogami: Jurnal Ilmiah Kajian Antropologi

E-ISSN : 2599-1078

antar generasi sebagai tanggapan pasca bencana. Tulisan mengenai Lumpur Lapindo, juga ditulis oleh Rusdi dan Mukarom (2014) dengan judul Perubahan Sosial di Daerah Pedesaan: Dampak Lumpur Lapindo di Kecamatan Porong Kabupaten Sidoarjo. Tulisan kedua ini menunjukkan adanya perubahan pada beberapa sektor sosial dalam kehidupan keluarga korban lumpur Lapindo. Berdasrkan kajian terhadap literatur mengenai Lumpur Lapindo, diketahui bahwa belum ada tulisan yang fokus membahas upaya pemulihan sosial ekonomi korban lumpur Lapindo dari awal bencana terjadi hingga mereka tinggal di tempat relokasi.

Penelitian ini menggunakan metode pendekatan etnografi dari Fetterman (2010:18-24) yang terdiri dari beberapa poin yaitu: (1) Holistic Perspective, misalnya penggambaran segala aspek kehidupan warga Renokenongo. (2) Kontekstualisasi, misalnya membantu memberikan karakterisasi yang lebih akurat terhadap lingkungan sosial. Kontekstualisasi perlu dilakukan terhadap kemunculan bencana lumpur Lapindo. Tujuan utama kontekstualisasi adalah untuk mengetahui hal yang melatarbelakangi perjuangan upaya pemulihan yang dilakukan masyarakat terdampak. (3) Perspektif emik. Perspektif dari warga Renokenongo membantu memahami mengapa mereka melakukan apa yang mereka lakukan. (4) Perspektif etik, merupakan interpretasi peneliti terhadap Lumpur Lapindo dan dampak sosial-ekonominya berdasarkan perspektif emik, serta (5) Nonjugdmental Orientation. Sementara itu, pemilihan informan dilakukan dengan menggunakan beberapa kategori yakni: (1) enkulturasi penuh, (2) keterlibatan langsung, (3) Suasana budaya yang tidak dikenal, (4) Waktu yang cukup, serta (5) Non-analitis (Spradley, 2007:68-77). Secara teknis, pemilihan infomarman menggunakan metode purposive sampling dan snowball sampling, dilakukan dengan cara mewawancarai pengurus paguyuban Pagar Rekontrak yang sekaligus menjadi koordinator sementara kompleks perumahan. Kemudian mewawancari informan yang sesuai dengan kriteria yang telah ditentukan, informan tersebut didapatkan berdasarkan informasi snowball dari pengurus Pagar Rekontrak. Selanjutnya digunakan analisis data model Miles dan Huberman (dalam Usman dan Akbar, 2009: 85-88) yang terdiri dari tiga tahapan yaitu (1) reduksi data, (2) penyajian data dan (3) penarikan kesimpulan.

\section{Dari Renokengono sampai Renojoyo: Alur pemulihan}

\subsection{Kedungsolo: Desa Tujuan Pasca Bencana Lumpur Lapindo}

Desa Kedungsolo merupakan wilayah administrasi Kecamatan Porong, Kabupaten Sidoarjo. Desa Kedungsolo berjarak kurang lebih $4 \mathrm{Km}$ dari tanggul penahan lumpur yang berada tepat di samping Jalan Raya Porong. Desa ini memiliki akses terhadap berbagai fasilitas umum seperti sekolah, pasar, dan rumah sakit. Profil Desa Kedungsolo 2016 menyebutkan bahwa desa ini terdiri dari hamparan dataran rendah dan merupakan daerah pertanian dan kawasan pemukiman, yang memiliki luas wilayah 106,50 Ha dengan jumlah penduduk 4302 jiwa. Desa Kedungsolo memiliki dua dusun yaitu Dusun Kedungsolo dan Kedung Kampil yang terbagi lagi dalam 4 RW dan 19 RT serta satu kawasan Perumahan Renojoyo.

Sarana dan prasarana yang dimiliki desa ini sudah terbilang lengkap. Dalam bidang kesehatan sarana yang tersedia meliputi 1 puskesmas, 1 bidan desa, dan 4 pelayanan 
posyandu, yang melayani perawatan kesehatan anak di setiap RW dengan kader posyandu 4 orang/pos. Puskesmas Kedungsolo merupakan puskesmas pembantu yang sudah memiliki peralatan yang cukup memadai (misalnya mobil ambulance, IGD dan ruang rawat inap). Untuk mendukung aktivitas olahraga, juga terdapat lapangan sepak bola, lapangan voli, bulu tangkis dan tenis meja. Sarana dalam bidang keagamaan berupa 2 masjid dan 10 langgar. Dalam bidang pendidikan terdapat 4 PAUD, 2 TK/RA, 2 SD/MI dan 9 TPQ. Di desa ini terdapat pula sungai sepanjang $2500 \mathrm{M}$ yang dipergunakan untuk irigasi sawah dan saluran pembuangan air dalam desa (Profil Desa Kedungsolo; 2016). Akses jalan sudah baik, jalan utama yang terdiri dari jalan kabupaten dan jalan desa sepanjang 2,5 Km yang sudah diaspal, sedangkan jalan lainya berupa gang-gang hampir seluruhnya sudah dipaving (Profil Desa Kedungsolo; 2016).

Tingkat mobilitas masyarakat tergolong rendah, tidak banyak orang yang merantau ke luar kota untuk bekerja ataupun keperluan lainnya. Hal tersebut semakin diperkuat dengan pertumbuhan penduduk yang selalu meningkat dari tahun ke tahun. Berikut data pertumbuhan penduduk Desa Kedungsolo:

Tabel 2.3 Data tingkat pertumbuhan penduduk Desa Kedungsolo

\begin{tabular}{|l|c|c|c|c|c|}
\hline \multicolumn{1}{|c|}{ Tahun } & $\mathbf{2 0 1 2}$ & $\mathbf{2 0 1 3}$ & $\mathbf{2 0 1 4}$ & $\mathbf{2 0 1 5}$ & $\mathbf{2 0 1 6}$ \\
\hline Jumlah pertumbuhan & 3.233 & 3.673 & 3.730 & 4188 & 4302 \\
\hline $\begin{array}{l}\text { Prosentase } \\
\text { pertumbuhan }\end{array}$ & $0,19 \%$ & $11,97 \%$ & $1,52 \%$ & $10,93 \%$ & $2,64 \%$ \\
\hline
\end{tabular}

Sumber: Profil Desa Kedungsolo tahun 2016

Pertumbuhan penduduk yang terus meningkat ini juga tidak lepas dari banyaknya pendatang baru, khususnya dari masyarakat terdampak bencana lumpur Lapindo dari wilayah yang lain. Sejak semburan lumpur menenggelamkan sebagian wilayah kecamatan Porong dan dua kecamatan lainnya, beberapa tanah di Desa Kedungsolo banyak yang dibeli oleh masyarakat terdampak bencana lumpur Lapindo untuk dijadikan sebagai area pemukiman. Salah satu wilayah tersebut terletak di Dusun Kedung Kampil yang dibeli oleh kelompok masyarakat terdampak dari Renokenongo untuk pendirian Perumahan Renojoyo.

\subsection{Pengungsian, Bedeng, Hingga Rumah Kontrakan Menjadi Hunian Sementara}

Sejak ledakan pipa gas Pertamina 22 November 2006, warga Renokenongo mulai mengungsi di Pasar Baru Porong. Hal ini dikarenakan luberan lumpur sudah memasuki area pemukiman, sebagian warga mulai menyelamatkan hartanya dengan menitipkan kepada kerabat yang rumahnya jauh dari pusat semburan. Selama di pengungsian Pasar Porong mereka berbagi fasilitas MCK. Pemakian fasilitas MCK yang digunakan secara bergiliran menjadi sebab munculnya penyakit gatal-gatal khususnya pada anak kecil, sedangkan para lansia banyak yang mengalami sesak napas akibat mengirup bau gas lumpur Lapindo.

Semburan lumpur juga mengakibatkan terganggunya kegiatan belajar para siswa sekolah. Jarak tempat relokasi sementara dengan sekolah mereka cukup jauh. Untuk 
mengatasi hal tersebut siswa mendapat bantuan antar jemput serta bimbingan belajar untuk siswa yang melaksanakan UN pada tahun ajaran 2006/2007. Pada tahun 2007 Pagar Rekontrak tergerak untuk mendirikan sekolah TK Al-Muhadjirin. Dasar utama pendirian TK ini adalah banyaknya anak usia 5-6 tahun yang terlantar di pengungsian, dan masyarakat terdampak tidak ingin anak-anaknya larut dalam kesedihan. TK ini tidak menargetkan siswanya bisa membaca atau menghitung karena tujuan utamanya adalah pendampingan psikologis terhadap anak terdampak bencana dan pemberian kegiatan positif untuk mengisi kekosongan waktu.

Selama di pengungsian, bantuan untuk pemulihan pasca bencana didapat dari donatur. Selain itu, anggota Pagar Rekontrak mencari bantuan secara bergiliran, misalnya meminta sumbangan di jalanan. Hasil sumbangan tersebut digunakan untuk memulihkan kondisi ekonomi dan kebutuhan sehari-hari. Sementara itu, upaya pemulihan sosial dilakukan oleh BPLS dengan pemberdayaan terhadap masyarakat melalui pelatihan keterampilan yang siap pakai. Beberapa jenis pelatihan yang dilaksanakan antara lain persepatuan, kelistrikan, mesin, pangan olahan, dan pertukangan.

Meskipun pengungsian sudah seperti kampung bagi warga Renokenongo, namun tinggal di pengungsian tidaklah aman bagi anak-anak, dan remaja khususnya perempuan. Oleh karena itu warga Renokenongo yang memiliki tabungan memutuskan untuk mengontrak rumah menggunakan uang pribadi. Tahun 2007 sedikit demi sedikit anggota Pagar Rekontrak keluar dari paguyuban. Mereka menerima uang kontrak karena sudah lama menderita di pengungsian. Sedangkan warga Renokenongo yang masih bertahan dalam Pagar Rekontrak berjumlah kurang lebih 500 KK. Pada tahun 2008, mereka menerima uang kontrak rumah dan skema pembayaran ganti rugi 20\%. Berbekal uang ganti rugi tersebut kemudian mereka keluar dari pengungsian dan melakukan rekolasi bersama di Desa Kedungsolo.

Sebanyak 160 anggota Pagar Rekontrak berpindah ke Desa Kedungsolo dengan membuat bedeng atau rumah semi permanen di tanah yang sudah mereka beli. Dalam memenuhi kebutuhan sehari-hari mereka menggunakan sisa uang kontrak yang diterima karena banyak dari mereka belum memiliki pekerjaan. Kebutuhan listrik disiasati dengan cara menyalur listrik. Karena Segala aktivitas belum memiliki fasilitas, aktivitas MCK dilakukan di sungai dekat Desa Kebonagung. Secara sosial, aktivitas relokasi yang dilakukan masyarakat Renokenongo di Desa Kedungsolo mengharuskan mereka melakukan adaptasi dengan masyarakat asli Kedungsolo.

\subsection{Perumahan Renojoyo: Bentuk Menghadirkan Kembali Renokenongo}

Relokasi bersama masyarakat Renokenongo di Desa Kedungsolo dikoordinir oleh Pagar Rekontrak. Awalnya dilakukan dengan membeli Tanah 10 hektar di Desa Kedungsolo dibagi menjadi 600 kapling tanah untuk tempat tinggal warga Renokenongo. Pada saat pembayaran menggunakan dana talangan dari salah satu warga. Untuk memiliki tanah tersebut, masyarakat membeli secara mencicil ke pengurus Pagar Rekontrak. Harga tanah per satu kapling tersebut mulai Rp.29.500.000. Selanjutnya dalam proses pembangunan rumah, pengurus Pagar Rekontrak menggandeng investor perumahan Real Estate Indonesia 
(REI) untuk membangun perumahan. Pembangunan rumah melalui jasa REI juga dibayar dengan mengangsur melalui bank Jatim. Harga rumah yang dibangun oleh REI pada periode pertama per satu unit rumah seharga Rp.55.000.000. Selain menggunakan REI untuk pembangunan, beberapa masyarakat juga membangun rumah secara mandiri. Akhirnya perumahan baru warga Renokenongo yang tergabung dalam Pagar Rekontrak di Desa Kedungsolo selesai dibangun pada tahun 2009 diberi nama Renojoyo yang berasal dari kata Renokenongo dan Joyo (jaya).

Bencana lumpur Lapindo yang terjadi menyisakan permasalahan terutama bagi masyarakat yang terdampak. Dalam konteks seperti ini dukungan keluarga dan keyakinan terhadap Tuhanlah yang mampu menengkan mereka yang mengalami beban psikologi. Walaupun Renokenongo sudah tenggelam, namun tradisi yang dulu terlaksana di Renokenongo tetap saja berjalan di Renojoyo misalnya slametan dan kenduren. Beberapa aktivitas sosial dan keagamaan juga tetap terlaksana seperti tahlilan untuk ibu-ibu dan bapak-bapak, terbangan di langgar untuk bapak-bapak dan pemuda, yasinan, manaqib, diba'an untuk para remaja dan ibu-ibu serta qubro NU. Dalam konteks ini dapat dilihat bahwa upaya menghadirkan kembali Renokenongo tidak hanya sekedar berkumpul dan bertetangga bersama-sama dengan warga Renokenongo lainnya. Upaya menghadirkan Renokenongo juga dilakukan dengan pendirian beberapa ruang publik seperti gardu/pos ronda yang terbuat dari bambu di setiap blok. Selain itu, didirikan fasilitas pendidikan TK dan TPQ, langgar disetiap blok, makam dan juga pos Karang Taruna. Para pemuda Renojoyo juga mulai membentuk organisasi Karang Taruna ditahun 2016. Organisasi ini dibentuk sebagai sarana berkumpulnya para pemuda Renojoyo guna mendukung dan mengurusi lingkungan sosialnya, misalnya mengadakan kerja bakti dan aktivitas lainnya.

Sementara itu, aspek ekonomi rumah tangga adalah salah satu aspek penting dalam pemulihan warga Renokenongo pasca bencana. Pemulihan ekonomi yang dilakukan selama ini diantaranya (1) memperjuangankan uang ganti rugi dan memanfaatkan untuk membeli tanah dan rumah; (2) memanfaatkan bantuan dari berbagai pihak (misalnya bantuan dari pemerintah, partai, LSM, dan kerabat); (3) dan mencari pekerjaan kembali bagi mereka yang kehilangan pekerjaan. Jika dilihat lebih jauh, setiap rumah tangga memiliki perbedaan bentuk dan lama waktu pemulihan khususnya dalam bidang ekonomi. Hal ini tergantung pada kemampuan akses yang juga didukung dengan status sosial (pendidikan, profesi dan pendapatan), penggunaan bantuan, dan adanya asuransi/bantuan.

\section{Akses Sebagai Sumber Daya: Aspek Penting Pemulihan Pasca Bencana}

Seperti yang diungkapkan Blaikie (2003) bahwa bencana terjadi karena adanya dampak bahaya pada orang-orang yang rentan, dimana kerentanan tersebut diakibatkan kondisi yang tidak aman dalam hal ekonomi dan sosial. Begitupun dengan masyarakat yang terdampak bencana lumpur Lapindo. Ternyata kerentanan yang dialami rumah tangga bervariasi. Setiap rumah tangga memiliki model pemulihan sosial ekonomi yang berbeda. Hal ini berkaitan dengan peran, bagaimana mereka mengatasi, mengembangkan strategi pemulihan, dan interaksi dengan aktor lain (lembaga donor). 
Setiap pemulihan kehidupan pasca bencana diperlukan sumber daya pemulihan. Terdapat empat kategori sumber daya pemulihan menurut Morrow (1999: 2-8), yaitu sumber daya perorangan (Human resources), sumber daya ekonomi (Economy resources), sumber daya sosial (Social resources) dan sumber daya politik (Political resources). Namun keempat sumber daya tersebut tidak bisa terlaksana tanpa adanya akses. Keempat sumber daya yang dijelaskan Morrow (1999) dalam kehidupan masyarakat telah tersedia, namun hanya saja mereka bisa atau tidak mengakses sumber daya tersebut untuk memulihkan kehidupannya pasca bencana. Menurut Blaikie (2003) kemampuan akses sumber daya selalu didasarkan pada hubungan sosial dan ekonomi, termasuk hubungan sosial produksi, jenis kelamin, etnis, status dan usia, hal ini menunjukkan bahwa hak dan kewajiban tidak merata diantara semua orang. Bentuk penggunaan 'akses' sebagai sumber daya dapat dilihat pada pemanfaatan berbagai sumber daya pemulihan yang tersedia pada masyarakat Renokenongo pada studi kasus bencana lumpur Lapindo berikut ini:

\subsection{Human Resources}

Individu selain menjadi objek bencana mereka adalah sumber daya yang tidak kalah penting dalam upaya pemulihan pasca bencana. Oleh karena itu, human resources diharapkan bisa pulih terlebih dahulu sehingga bisa mendukung pemanfaatan peluang untuk mengakses sumber daya lainnya. Hal yang perlu dipulihkan dari human resources misalnya kesehatan, psikologis, pengetahuan dan keterampilan menghadapi bencana.

Ketika pendapatan ekonomi keluarga Pak Mulyadi mandek karena mata pencahariannya terendam lumpur, beliau mulai memutar otak. Akhirnya menemukan mata pencaharian sementara dengan memanfaatkan rumah-rumah yang terendam lumpur sebagai ladang mencari nafkah dengan mengambil bahan bangunan yang bisa dijual kembali. Dalam konteks ini Pak Mulyadi memiliki kemampuan untuk memanfaatkan peluang yang ada. Dalam pemulihan ekonomi rumah tangga, sumber daya manusia dalam hal ini anggota rumah tangga memiliki pengaruh yang besar. Hal tersebut dilihat dari sumber daya manusia (human resources) sebagai anggota rumah tangga mampu atau tidak dalam melanjutkan pekerjaannya dan menghasilkan pendapatan dari aset finansial.

Peran human resources tidak hanya berlaku dalam pemulihan ekonomi, tetapi juga dalam pemulihan sosial rumah tangga. Seorang janda seperti Bu Iswahyu Ningsih menurut banyak penelitian lebih susah dalam melakukan upaya pemulihan karena termasuk kategori

rentan. Namun hal tersebut tidak terjadi pada Bu Iswahyu Ningsih baik dari sisi pemulihan sosial maupun ekonomi. Beliau adalah perempuan yang aktif selama masa perjuangan menuntut hak ganti rugi sehingga ia lebih mudah untuk bersosialisasi dengan orang lain. Sebagai seorang muslim beliau selalu bersyukur kepada Tuhan dengan kondisi hidupnya saat ini, walaupun beliau adalah yang paling 'tidak punya' diantara seluruh saudara kandungnya. Keyakinannya membuatnya semakin kuat untuk menghadapi hidupnya sekarang. Pemanfaatan atau akses human resources ini bergantung pada kemampuan individu yang menjadi korban bencana untuk memanfaatkan diri mereka sendiri yang juga berpotensi sebagai sumber daya pemulihan kehidupan pasca bencana. Individu produktif, 
Endogami: Jurnal Ilmiah Kajian Antropologi

E-ISSN : 2599-1078

usia dewasa yang memiliki psikologis baik akan lebih mudah untuk mengakses human resources yang ada dalam diri mereka.

\subsection{Social Resources}

Lingkungan sosial masyarakat yang didalamnya terdapat jaringan-jaringan sosial merupakan salah satu sumber daya yang penting ketika terjadi bencana. Seperti yang berlaku pada warga Renokenongo yang tergabung dalam Pagar Rekontrak. Adanya ikatan sosial yang baik antar warga sehingga memunculkan paguyuban yang menaungi anggotanya. Pagar Rekontrak merupakan sumber daya sosial (Social Resources) yang memiiliki peran dalam proses pemulihan anggotanya. Bukti bahwa sumber daya sosial Pagar Rekontrak berjalan dengan baik adalah adanya keputusan anggota untuk tinggal bersama kembali di Perumahan Renojoyo.

Sumber daya sosial yang dimanfaatkan oleh warga Renokenongo bukan hanya dari paguyuban yang mereka ikuti. Bu Iswahyu Ningsih dan Pak Bambang mendapatkan bantuan dari saudaranya berupa tempat untuk menampung sementara perabotan rumah tangga mereka. Selain itu Bu Iswahyu Ningsih dan sekeluarga, dimana yang posisinya adalah sebagai seorang janda selalu mendapat dukungan baik moril maupun materiil dari saudara-saudara kandungnya yang tidak menjadi korban lumpur Lapindo. Lindell (2013) menjelaskan rumah tangga yang berusia lanjut, dikepalai wanita, berpendapatan rendah, dan etnis minoritas biasanya memiliki kerentanan yang lebih tinggi terhadap bencana. Namun dalam contoh keluarga Bu Iswahyuni tidak terjadi kesulitan, sebab keluarga ini memiliki jaringan sosial yang baik dengan sesama anggota keluarganya.

Bagi warga Renokenongo yang tidak bergabung dengan Pagar Rekontrak, bukan berarti mereka tidak bisa mengakses sumber daya sosial untuk pemulihan. Keluarga Bu Daumi, walaupun memutuskan untuk pindah secara individu di Desa Kedungsolo masih bisa mengakses sumber daya sosial. Sumber tersebut didapatkan dari para saudaranya serta anggota keluarga intinya yang berjumlah 7 orang. Selain itu keluarga ini bisa dengan mudah mendapat sumber daya sosial pada tetangganya yang asli warga Desa Kedungsolo, pasalnya seluruh anggota keluarga ini bersifat sederhana, ramah dan tak sungkan untuk memulai interaksi dengan warga asli Kedungsolo.

\subsection{Economy Resources}

Selain pemanfaatan sumber daya sosial (Social resources), pemulihan pasca bencana juga mutlak memanfaatkan sumber daya ekonomi. Sebab sumber daya ekonomi inilah yang akan berperan besar dalam mengembalikan kondisi fisik dan perekonomian rumah tangga masyarakat terdampak. Dalam kasus bencana lumpur Lapindo, uang ganti rugi yang diberikan oleh PT.LBI adalah segalanya bagi para korban, sebab hanya dengan uang ganti rugi itulah mereka bisa memulihkan kehidupannya dengan membeli tanah dan rumah lagi, khususnya bagi mereka yang tidak memiliki uang tabungan lebih.

Semua korban warga Renokenongo dapat mengakses dana ganti rugi sesuai jumlah asetnya yang tenggelam ataupun bantuan uang tunai dari pemerintah/presiden yang dibagi 
secara merata. Uang ganti rugi tanah dan bangunan yang didapatkan oleh korban lumpur Lapindo jauh lebih besar daripada harga pasaran. Walaupun ganti rugi jumlahnya ratusan juta tetapi dibayar oleh Lapindo secara mengangsur dan itupun selama lebih dari dua tahun mulai akhir 2012 mengalami kemacetan pencairan. Dilain posisi banyak diantara para korban yang kehilangan pekerjaan, uang cicilan ganti rugi tersebut juga mereka gunakan untuk menyambung kehidupan. Jika uang ganti rugi dan dana bantuan dari pemerintah/presiden bisa diakses oleh semua korban lumpur Lapindo, namun kemampuan memanfaatkan sumber tersebut tidak akan sama. Begitu juga dengan kemampuan akses mereka akan berbeda terhadap sumber ekonomi yang berupa mata pencaharian, ataupun bantuan ekonomi dari kerabat.

Seperti keluarga Bu Anis yang memanfaatkan uang ganti rugi dengan baik karena keluarga ini tidak kehilangan seluruh pendapatan selama bencana terjadi. Aset yang dimiliki keluarga ini semakin bertambah dari aset sebelumnya di Renekenongo, berkat ganti rugi Lapindo beliau bisa membuatkan rumah untuk anaknya. Lain lagi dengan Pak Mulyadi yang tidak memiliki pendidikan tinggi sehingga tidak semua pekerjaan bisa dilakukan. Beliau berusaha mengembalikan kondisi ekonominya dengan mencoba menekuni pekerjaan sebagai pedagang warung di tempat baru dengan memanfaatkan uang ganti rugi sebagai modal dagang.

\subsection{Political Resources}

Berbicara soal sumber daya politik akan berkaitan dengan kekuasaan. Pagar Rekontrak merupakan organisasi resmi dan terstruktur, pemanfaatan sumber daya politik dapat dilihat didalamnya. Sumber daya politik dalam konteks pemulihan warga Renokenongo tidak terlihat begitu dominan. Sebab pemanfaatan kekuasaan hanya dimanfaatkan oleh beberapa orang yang memiliki kuasa, dalam hal ini misalnya pengurus. Seperti yang sudah disebutkan pada awal subab ini mengenai hak istimewa yang diminta oleh pengurus Pagar Rekontrak tentang lokasi tanah kapling mereka.

Begitu pula saat di pengungsian, semua bantuan yang datang ke paguyuban tersebut selalu diterima oleh para pengurus terlebih dahulu kemudian didistribusikan kepada anggota. Dari perbedaan-perbedaan kuasa ini tidak jarang menimbulkan percekcokan dalam kelompok. Dalam periode pemulihan, biasanya terdapat adanya ketidakpuasan korban dalam pembangunan kembali dan menciptakan adanya perbedaan kepentingan yang menimbulkan konflik horizontal maupun vertikal. Sebenarnya sumber daya politik berupa kebebasan menyatakan pendapat bisa dilakukan untuk menghindari hal tersebut. Namun kembali lagi bahwa untuk mengakses sumber daya politik akan berkaitan dengan status sosial atau kuasa yang dimiliki dalam masyarakat.

Dari empat jenis sumber daya pemulihan yang ada, mereka memiliki peranan yang saling berkaitan tidak bisa dipisahkan. Human resources yang berkulitas tinggipun tidak akan bisa melakukan pemulihan tanpa ada dukungan yang cukup dari sumber daya yang lain. Economy resources yang melimpahpun tidak akan berkembang apabila tidak ada human resources yang baik. Adanya social resources juga mempermudah akses warga terhadap economy resources dan melakukan pemulihan sosial pada khususnya. Keberhasilan yang 
dibarengi dengan keuntungan dalam pemulihan ekonomi dan sosial juga tak jarang didukung oleha adanya political resources. Keterkaitan peran keempat sumber daya pemulihan yang sudah tersedia dan sekaligus didukung oleh kemampuan 'akses' yang mereka miliki membuat para korban bencana dapat memulihkan kehidupan seperti sediakala atau bahkan menjadi lebih baik.

\section{Simpulan}

Hasil penelitian ini menjelaskan upaya pemulihan dari segi sosial-ekonomi yang selama ini dilakukan masyarakat Renokenongo hingga kehidupan mereka kembali pulih. Pemulihan sosial-ekonomi yang dilakukan adalah dengan memanfaatkan empat jenis sumber daya pemulihan yang ada yaitu sumber daya manusia, sumber daya ekonomi, sumber daya sosial, dan sumber daya politik. Keberhasilan pemulihan tersebut tidak lepas dari kemampuan akses sumber daya yang mereka miliki.

Berikut upaya pemulihan sosial yang dilakukan warga Renokenongo adalah (1) Membentuk Pagar Rekontrak untuk melakukan serangkaian pemulihan bersama; (2) Pemulihan perumahan mulai dari tinggal di pengungsian, di bedeng, dan beberapa diantaranya ada yang mengontrak rumah hingga akhirnya melakukan relokasi di Perumahan Renojoyo ataupun pindah mandiri di Desa Kedungsolo; (3) Pemulihan pendidikan, mendirikan TK Al-Muhajdirin dan mendirikan TPQ; (4) Pemulihan sosial keagaamaan, mendirikan kembali beragam organisasi keagaam dan organisasi sosial, beberapa warga mewakafkan tanahnya untuk langgar dan makam; (5) Bidang psikologis, warga yang masih trauma hingga saat ini selalu mendapat dukungan dari keluarga.

Pemulihan ekonomi yang dilakukan warga selama ini diantaranya (1) memperjuangankan uang ganti rugi dan memanfaatkan untuk membeli tanah dan rumah; (2) memanfaatkan bantuan dari berbagai pihak (misalnya bantuan dari pemerintah, partai, LSM, dan kerabat); (3) dan mencari pekerjaan kembali. Setiap rumah tangga memiliki perbedaan bentuk dan lama waktu pemulihan khususnya dalam bidang ekonomi, hal ini tergantung pada kemampuan akses yang juga di dukung dengan status sosial (pendidikan, profesi dan pendapatan), penggunaan bantuan, dan adanya asuransi/bantuan.

\section{Daftar Pustaka}

Batubara, B., \& Utomo, P. W. 2012. Kronik Lumpur Lapindo, Skandal Bencana Industri Pemboran Migas di Sidoarjo. Yogyakarta: Insist Perss.

Coppola, D.P. 2007. Introduction to International Disaster Management. Oxford: ButterworthHeinemann.

Damanik, Caroline. 2015. Pulihkan Hak-hak Warga Korban Lumpur Lapindo. Harian Kompas. Diakses $\quad$ tanggal $\quad 1 \quad$ November 2016 dari http://regional.kompas.com/read/2015/05/13/19000031/Pulihkan.Hakhak.Warga.Korban.Lumpur.Lapindo 
Endogami: Jurnal Ilmiah Kajian Antropologi

E-ISSN : 2599-1078

Fauzan, A. U; dan Batubara, Bosman. 2010. Displacement and Changing Gender and Intergenerational Relation: Experience of Hot Mudflow Affected Families in East Java, Indonesia. International Conference on Economic Stress, Human Capital, and Families in Asia: Research and Policy Challenges, (hal. 1-11). Singapore.

Fetterman, D. M. 2010. Ethnography Step-by-Step Third Edition. London: SAGE.

Kusumasari, Bevaloa. 2014. Manajemen Bencana dan Kapabilitas Pemerintah Lokal. Yogyakarta: Gava Media.

Lindell, M. K. 2013. Recovery And Reconstruction After Disaster. Encyclopedia of Natural Hazards, 812-824.

Morrow, B.H. 1999. Identifying and Community Vulnerability. Disasters, 23(1): 1-18.

Rusdi \& Mukarom. 2014. Perubahan Sosial di Daerah Pedesaan: Dampak Lumpur Lapindo di Kecamatan Porong Kabupaten Sidoarjo. Humaniora, 5-13

Spradley, James P. 2006. Metode Etnografi. Yogyakarta: Tiara Wacana.

Usman, H., \& Akbar, P.S. 2009. Metodologi Penelitian Sosial. Edisi kedua. Jakarta: Bumi Aksara.

Wisner, B., P. Blaikie. T. Cannon., and I. D. 2003. At Risk: Natural Hazards, People' s Vulnerability and Disasters (Second). London: Routledge.

Profil Desa Kedungsolo 2016 